\title{
How Waterlogged Conditions Influence the Nitrogen Removal Performance in a Micro Constructed Wetland
}

\section{Lumeng Xie}

Beijing Forestry University

Ying Liu

Beijing Forestry University

\section{Shiqiang Zhao}

Beijing Forestry University

\section{Liyi Dai}

Beijing Forestry University

Mingxiang Zhang

Beijing Forestry University

Zhenming Zhang ( $\nabla$ zhenmingzhang@bjfu.edu.cn )

Beijing Forestry University

\section{Research Article}

Keywords: eutrophication, waterlogged conditions, wetland plant, and water purification

Posted Date: May 13th, 2021

DOl: https://doi.org/10.21203/rs.3.rs-465070/v1

License: (9) (i) This work is licensed under a Creative Commons Attribution 4.0 International License. Read Full License 


\section{Abstract}

Growing populations and industrialization have led to raised wetland ecosystems nitrogen $(\mathrm{N})$ loads. A micro constructed wetland planted with Lythrum salicaria $L$ treating an artificial wastewater was used to investigate the short-term variations in the plant biomass and the removal efficiency of $\mathrm{N}$. Our results showed that the biomass of Lythrum salicaria $L$. increased rapidly during the experiment due to their extensive root system and vigorous spread, and waterlogged conditions had little effect on the relationship between biomass and the concentration of TN in soil and effluent. Under different waterlogged conditions, the removal rates of TN in the water were all more than $60 \%$, providing a reference for waterlogged conditions used in wetland eutrophication restoration.

\section{Introduction}

The rapid development of society and agricultural intensification has improved living standards but also caused various water-related issues, especially pollution and degradation of wetland ecosystems (Abi Saab et al. 2018, Meng et al. 2019, Van Meter et al. 2017). Moreover, the condition is getting worse in the developing economies because of the integrated effect of anthropogenic activities, escalating demand of resources, and the population explosion(Suhani et al. 2020). According to World Water Assessment Programme (WWAP), over $80 \%$ of wastewater is discharged untreated into natural waterways (WWAP 2017), the retention of excessive nutrients will seriously affect the wetland's ecological services.

Wetlands are ecotone between land ecosystems and aquatic ecosystems; as such, they represent a special natural complex with unique hydrological characteristics (Maltby 1991). The plant communities, soil properties, and biogeochemical cycling in wetland systems are affected by water level fluctuations and associated processes (Bai et al. 2005, Luo et al. 2016, Unger et al. 2009). Hydrological regime also control the evolution of the wetland, which is the most important variable in the formation and maintenance of special wetland types (such as coastal wetland, swamp, and marsh) and processes.

In the other hand, wetlands are among the crucial nature-based solutions for river water purification, the traditional perception of wetlands as nutrient sinks has led them to be used as wastewater disposal areas. The ecological quality of these multi-purposed ecosystems could be disrupted due to overloading of nutrients and other pollutants(Sileshi et al. 2020), excessive loading of nutrient elements into the natural water bodies enhancing the risk of eutrophication, so effective and cost efficient onsite treatment to remove the contaminants is a critical issue in water protection and risk mitigation(Bavandpour et al. 2018).

Plants offer an added benefit to wetland restoration and are effective in mitigating wetland eutrophication by absorbing, assimilating, and reutilizing nutrients such as nitrogen and phosphorus in the water body and sediment to support their own physiological processes and growth for the following year (Aerts and Chapin 1999, Deegan et al. 2007, Gan et al. 2011, Ge et al. 2017, Ling and Li 2018, Rejmankova 2005).Wetland plants root share some common characteristics such as providing oxygen 
and secrete oxygen to form aerobic, facultative and anaerobic micro-environments around the rhizosphere, thereby promoting the degradation of pollutants in sewage by microbial nitrification and denitrification(Mic et al. 2019). And the ability to accumulate different element concentrations in various organs is good predictors of the nutrient resorption efficiencies and proficiencies of wetland(Bonanno et al. 2018, Pan et al. 2019, Wang et al. 2015).

Waterlogged events impact soil properties and modify enzyme activities (Ou et al. 2019), and alternating waterlogged conditions can significantly increase nutrient removal efficiency compared with permanently flooded soils and non-flooded soils (Tootoonchi et al. 2018). When $\mathrm{O}_{2}$ becomes less available and soil redox potential becomes more reduced, slow organic matter decomposition may result in accumulation of dissolved organic carbon (Moorberg et al. 2015). Redox potential decreases more slowly under flooding-draining soils than under permanently flooded soils (McHergui et al. 2014). The aerobic/anaerobic biogeochemical equilibrium, nutrient inputs and outputs, and the structure of plant communities could in all likelihood be strongly disturbed during the waterlogged process and could further impact the contents of soil nutrients.

Previous researchers have focused on nitrogen removal in wetland systems under the condition of single wetland plants or a variety of wetland plant ecological combinations(Li et al. 2021), as well as system nitrogen retention under constant conditions (Audet et al. 2020, Cheng et al. 2020, Yu et al. 2012); however, these studies did not always relate waterlogged conditions to the removal performance of nutrient elements. Here we use a micro constructed wetland system to simulate the nitrogen removal process under different waterlogged conditions; track dynamic changes in nitrogen elements, further clarify the impact of different waterlogged conditions on plant growth, pollutant removal, and nitrogen retention. At the same time, the prospects for the future research focus on the purification and restoration of wetland pollution under different waterlogged conditions are put forward, which lay the theoretical foundation and provide reference for the selection of waterlogged condition for further wetland restoration.

\section{Materials And Methods Material preparations}

The study was carried out from June 2018 to October 2018. Considering both its pollution resistance and tolerance, we selected $L y$ thrum salicaria $L$, a type of ornamental wetland plant species that can grow vigorously under different environment conditions(Bastlová and Květ 2002, J. et al. 2002). Plant samples were purchased in a horticultural company online (www.taobao.com) in June 2018. 12 individuals were ultimately planted evenly in each compartment of flumes for one month; the growth of individuals in each flume was approximately the same.

The experimental water was a high-concentration eutrophication sewage prepared in the laboratory; its main reagents and target concentrations are shown in Table 1. Distilled water was used to water the 
plants every three days during the experimental period. Then influent nutrient concentrations greatly exceeded the range of environmental limit values.

\section{Table 1}

Artificial sewage water characteristics

\begin{tabular}{|llll|}
\hline Constituent & $\begin{array}{l}\mathrm{TN} \\
(\mathrm{mg} / \mathrm{L})\end{array}$ & $\begin{array}{l}\mathrm{TP} \\
(\mathrm{mg} / \mathrm{L})\end{array}$ & $\begin{array}{l}\mathrm{COD} \\
(\mathrm{mg} / \mathrm{L})\end{array}$ \\
\hline Concentration & 40 & 4 & 300 \\
\hline Reagent & $\mathrm{NH}_{4} \mathrm{Cl}$ & $\mathrm{KH}_{2} \mathrm{PO}_{4}$ & $\mathrm{C}_{6} \mathrm{H}_{12} \mathrm{O}_{6}$ \\
\hline $\begin{array}{l}\text { a The configuration of the artificial sewage was adopted from a similar experiment (Ling and Li } \\
\text { 2018). }\end{array}$
\end{tabular}

The experiment was located in a greenhouse at Beijing Forestry University in Haidian District. During the experiment, the mean temperature was $25^{\circ} \mathrm{C}$ and the relative humidity was $74.2 \%$. We set up flume (shown in Fig 1) containing six compartments filled with $0.12 \mathrm{~m}$ deep non-contaminated soil collected from outside of the greenhouse to simulate the conditions of a surface flow constructed wetland. In order to collect water samples during the experiment, two outlets were placed $0.1 \mathrm{~m}$ and $0.2 \mathrm{~m}$ from the lower edge of the flume. We used a steel canopy to prevent rain entering the system.

\section{Sample treatment}

We used a completely randomized design, and the experiment considered two factors (shown in Table 2):

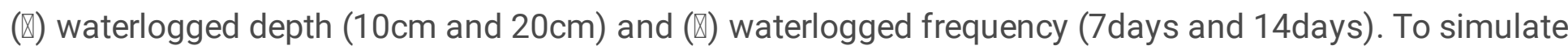
the hydrological fluctuation scenarios naturally occurring in a wetland, we conducted four treatments: $(\mathbb{\nabla})$ high waterlogged frequency and low waterlogged depth, ( $(\mathbb{)})$ high waterlogged frequency and high

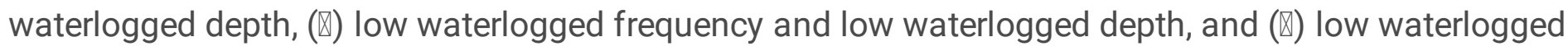
frequency and high waterlogged depth. The experiment was conducted indoors in four flumes, with three replicates in each treatment.

The artificial pollution water was kept in plastic buckets, carried from the laboratory to the greenhouse, and released into the flumes before starting the experiments. In order to keep the waterlogged depth unchanged, we added water to the flumes every two days to compensate for losses due to evaporation. For high waterlogged frequency, we drained off water every 7 days, whereas for low waterlogged frequency, we drained off water every 14 days. 


\section{Sample collection and analysis}

As the water passed through each compartment of the flumes, the biomass and TN concentrations of the water and soil were monitored. We collected plant, soil, and water samples every seven days from each compartment of the flumes. All plant and soil samples were placed in plastic bags and immediately brought to the laboratory. The plants samples were first washed with running tap water, and air dried at room temperature for two weeks. Recognizable plant litter, coarse root materials, and stones were removed from the plant and soil samples.

Fresh plant samples were separated into their above- and below-ground components and then dried in an oven at $70^{\circ} \mathrm{C}$ for $48 \mathrm{~h}$ for dry weight determination. Dried soil samples were ground, wet digested, and analyzed for $\mathrm{TN}$. The water samples were placed in plastic bottles and stored at $2{ }^{\circ} \mathrm{C}$ prior to analysis. We used an Elemental Analyzer (Vario El, Elementar Co., Germany) to obtain the TN content.

\section{Statistical analysis and graphing}

All experimental data are presented as average values. One-way ANOVA analysis was conducted to reveal the differences in average biomass and TN content between the high waterlogged frequency/low waterlogged frequency and high waterlogged depth/low waterlogged depth treatments. The data obtained in the experiment were edited and processed by Microsoft Excel 2007 software, relevant charts were drawn using Sigmaplot 12.5 software, one-way ANOVA analysis and Chi-Square tests was carried out using SPSS22.0. The formula for TN removal rate was as follows:

$$
\text { Removal rate }(\%)=\frac{C_{0}-C_{1}}{C_{0}} \times 100 \%
$$

where $\mathrm{C}_{0}$ is the initial concentration and $\mathrm{C}_{1}$ is the concentration at time of sampling.

\section{Results}

\subsection{Dynamic changes in average biomass under different waterlogged conditions}

Generally, the aboveground biomass first increased and then decreased with increasing experiment time. The changes in aboveground biomass for high waterlogged frequency were similar to those at low frequency, although the values were slightly higher for the low waterlogged frequency (Fig. 2a). The initial aboveground biomass was $3.05 \pm 0.30 \mathrm{~g}$, and it reached maximum value of $4.73 \pm 0.47 \mathrm{~g}$ under the high waterlogged frequency and $5.05 \pm 0.82 \mathrm{~g}$ under the low waterlogged frequency at 42 days. 
The underground biomass increased gradually during the experimental period under different waterlogged conditions. At the beginning ( 0 to 14 days) and end (last 28 days) of the experiment, the underground biomass under the high waterlogged frequency was higher than that under the low waterlogged frequency (Fig. 2b). For the high waterlogged frequency condition, underground biomass increased from $2.42 \pm 0.37 \mathrm{~g}$ to $12.58 \pm 0.63 \mathrm{~g}$, whereas it was $11.77 \pm 0.74 \mathrm{~g}$ at the end of the experiment under the low waterlogged frequency. Results of the one-way ANOVA showed that waterlogged frequency did not affect the aboveground $(P=0.103>0.05)$ or underground $(P=0.961>0.05)$ biomass of the wetland plant.

At low waterlogged depth, the aboveground biomass decreased from $3.05 \pm 0.30 \mathrm{~g}$ to $2.58 \pm 0.23 \mathrm{~g}$ over the course of the experiment, with the maximum value of $4.23 \pm 0.71 \mathrm{~g}$ occurring on the 28th day. At high waterlogged depth, the aboveground biomass decreased from $3.05 \pm 0.30 \mathrm{~g}$ to $2.63 \pm 0.31 \mathrm{~g}$ over the entire experiment, with the maximum $(4.97 \pm 0.63 \mathrm{~g})$ occurring at 35 days after treatment (Fig. $2 \mathrm{c})$.

The underground biomass displayed clear trends in the experiment, all curves increased, and we observed that the value under the low waterlogged depth was always higher than that under the high waterlogged depth (Fig. 2d). The fastest growth of the underground biomass was between the 21st and 42nd day. Results of one-way ANOVA showed that waterlogged depth did not affect aboveground $(P=0.796>0.05)$ or underground $(P=0.693>0.05)$ biomass of the wetland plant. Results of Chi-Square Tests showed that different waterlogged conditions have no effect on plant growth $(P=0.271>0.05$ for aboveground biomass, $P=0.349>0.05$ for underground biomass).

\subsection{Dynamic changes in total nitrogen content under different waterlogged conditions}

Results of Chi-Square Tests showed that different waterlogged conditions have no effect on TN content in soil $(P=0.814>0.05)$ and effluent $(P=0.754>0.05)$. At the beginning of the experiment, the soil TN content was $0.45 \pm 0.03 \mathrm{~g} / \mathrm{kg}$, with this value changing during the experiment. Under the high waterlogged frequency condition, it increased from 0 to 35 days, before falling smoothly from $0.62 \pm 0.02 \mathrm{~g} / \mathrm{kg}$ to 0.54 $\pm 0.038 \mathrm{~g} / \mathrm{kg}$ and then rebounding slightly after 49 days. Under the low waterlogged frequency condition, the value increased from 0 to 14 days, decreased on the 21 st day, and the continued to rise from 21 to 35 days, reaching a maximum content of $0.63 \pm 0.045 \mathrm{~g} / \mathrm{kg}$ on the 35th day. Under the two experimental conditions, the TN content at each sampling time was higher than that at the beginning of the experiment (Fig. 3a). One-way ANOVA showed that different waterlogged frequencies did not affect the content of TN in soil $(P=0.300>0.05)$.

The TN content of the effluent represents the purification capacity of the wetland plants. As for the dynamic changes in effluent TN content under each waterlogged frequency, the overall trend during the experiment was decreasing, although there was a slight increase in the later period of the experiment (Fig. 3b). There were five periods under a high waterlogged frequency and three periods under a low waterlogged frequency. Compared with the influent, the TN content in the effluent was significantly lower. The average removal rate of TN is shown in Table 3. 
Table 3

Average removal rate of effluent total nitrogen under different waterlogged frequencies

\begin{tabular}{|c|c|c|c|c|c|}
\hline & Period *1 & Period 2 & Period 3 & Period 4 & Period 5 \\
\hline \multirow[t]{2}{*}{$\begin{array}{l}\text { High waterlogged } \\
\text { frequency }\end{array}$} & $\begin{array}{l}76.8 \pm \\
2.1 \%\end{array}$ & $87.6 \pm 1.6 \%$ & $85.4 \pm 1.9 \%$ & $78.5 \pm 4.1 \%$ & $77.6 \pm 4.5 \%$ \\
\hline & Period* 1 & Period 2 & Period 3 & & \\
\hline Low waterlogged frequency & $\begin{array}{l}88.0 \pm \\
3.9 \%\end{array}$ & $89.2 \pm 1.9 \%$ & $84.9 \pm 4.4 \%$ & & \\
\hline
\end{tabular}

Short-term changes in waterlogged depth were associated with the fluctuations in soil TN content. With increasing inputs of artificial simulated pollution water, the general trend in soil TN content was an initial increase followed by a decrease (Fig. 3c). Under the low waterlogged depth, the TN maximum value was observed on the 35th day, after which it declined slowly. Under the high waterlogged depth, the peak TN content of occurred on the 21st day. We also observed that the TN content of each sample was higher than that at the beginning of the experiment. The one-way ANOVA indicated that waterlogged depth did not affect soil TN concentration $(P=0.366>0.05)$.

Overall, TN content in effluent under different waterlogged depths showed a downward trend during the experiment (Fig. 3d). On the 35th day, the TN content of the effluent was $3.81 \pm 0.24 \mathrm{mg} / \mathrm{L}$ under the low waterlogged depth and $10.59 \pm 3.32 \mathrm{mg} / \mathrm{L}$ under the high waterlogged depth, which was a significant difference. The TN removal rate of the system was more than $60 \%$. In general, the system could remove the TN in the water during the plant growth period, and the overall removal rate showed an increasing trend. Table 4 shows the TN average removal rates. The one-way ANOVA analysis showed us different waterlogged depths did not affect the TN concentration in effluent $(P=1.00>0.05)$.

Table 4

Average removal rate of effluent total nitrogen under different waterlogged depth

\begin{tabular}{|c|c|c|c|c|c|c|c|c|c|}
\hline & 7 & 14 & 21 & 28 & 35 & 42 & 49 & 56 & 63 \\
\hline $\begin{array}{l}\text { High } \\
\text { waterlogged } \\
\text { depth }\end{array}$ & $\begin{array}{l}75.5 \\
\pm \\
2.9 \%\end{array}$ & $\begin{array}{l}72.0 \\
\pm \\
7.4 \%\end{array}$ & $\begin{array}{l}87.7 \\
\pm \\
1.4 \%\end{array}$ & $\begin{array}{l}86.9 \\
\pm \\
2.6 \%\end{array}$ & $\begin{array}{l}72.4 \\
\pm \\
0.6 \%\end{array}$ & $\begin{array}{l}85.9 \\
\pm \\
1.1 \%\end{array}$ & $\begin{array}{l}88.1 \\
\pm \\
0.4 \%\end{array}$ & $\begin{array}{l}88.8 \\
\pm \\
1.6 \%\end{array}$ & $\begin{array}{l}88.9 \\
\pm \\
1.5 \%\end{array}$ \\
\hline $\begin{array}{l}\text { Low } \\
\text { waterlogged } \\
\text { depth }\end{array}$ & $\begin{array}{l}78.2 \\
\pm \\
0.9 \%\end{array}$ & $\begin{array}{l}63.1 \\
\pm \\
8.4 \%\end{array}$ & $\begin{array}{l}88.9 \\
\pm \\
0.8 \%\end{array}$ & $\begin{array}{l}87.8 \\
\pm \\
2.6 \%\end{array}$ & $\begin{array}{l}90.1 \\
\pm \\
8.5 \%\end{array}$ & $\begin{array}{l}90.2 \\
\pm \\
0.8 \%\end{array}$ & $\begin{array}{l}88.0 \\
\pm \\
2.9 \%\end{array}$ & $\begin{array}{l}89.1 \\
\pm \\
2.3 \%\end{array}$ & $\begin{array}{l}88.4 \\
\pm \\
1.4 \%\end{array}$ \\
\hline
\end{tabular}

\section{Discussion}

As shown by the results of the statistical analysis, different waterlogged conditions had no link between biomass and TN content in the wetland system. I think one of the possible reasons may be that this 
constructed wetland system was not sensitive to waterlogged conditions we designed, the two different waterlogged conditions are similar to the constructed wetlands system. But some general rules were observed based on the change trends, and we have some implications for wetland water environment restoration.

Wetland soil contributes greatly to water purification, nutrient accumulation, and regeneration of nitrogen, with its function largely dependent on plant community structure(Gumbricht 1993). The notable reductions in effluent TN content indicated that this constructed wetland was able to remove TN from the influent water and that the ability of the investigated soil to retain TN was also high. To a certain extent, the increase of plant biomass indicated that the $\mathrm{N}$ in different forms is assimilated and absorbed by wetland plants (Sun et al. 2019, Zak et al. 2014), and vegetation harvesting may simulate the overall N removal(Jabońska et al. 2020), those processes also caused the decrease of TN content in water. Vegetation covering was essential to the enrichment of $\mathrm{TN}$, indicating the importance of biologically related fixation in wetland soil (Ge et al. 2017).

According to the changes in biomass at the beginning of the experiment, the plants grew vigorously because eutrophication stimulates the growth of wetland plant life (Azhdarpoor et al. 2018). Waterlogged condition is an important factor affecting the growth and reproduction of wetland plants, with different wetland plants having different requirements in relation to waterlogged condition; moreover, the change in biomass is a comprehensive response to the change in external environment(McConnaughay and Coleman 1999). In this experiment, for both high and low waterlogged frequencies, an increasing then decreasing trend in aboveground biomass was observed. The aboveground biomass continued to decline in the later period of the experiment, which may have been related to weather and the physiological state of the plant. Overall, aboveground biomass was higher under low waterlogged frequency, and the belowground biomass was higher under high waterlogged frequency, indicating that $L y$ thrum salicaria $L$. may be less productive with a fluctuating water level than with a stable water level. We also observed that most of the biomass was concentrated in the belowground portion; therefore, Lythrum salicaria L. may rely on increasing its root biomass to acquire nitrogen from soil under a eutrophic environment. In response to waterlogged stress, the general strategy of plants is to extend the stem, the biomass of the aboveground portion will be relatively large(Busch et al. 2004). When the waterlogged depth is less than 1 $\mathrm{m}$, some emergent plants will also distribute more biomass to the stem (Rea and Ganf 1994). Water level fluctuation will also intermittently reduce the atmospheric sources of carbon and oxygen; therefore, if the plant is submerged for a long time, it will force its below-ground portion to carry out anaerobic respiration, which quickly depletes the carbohydrate reserve and reduces net growth (Deegan et al. 2007). From another point of view, in addition to being affected by water level, some wetlands plants are also greatly affected by the nutrient conditions of the substrate(Vojtíšková et al. 2004, Xie et al. 2005).

During the experiment, the content of TN in the soil was higher than that at the beginning of the experiment, which indicates that nitrogenous components of the water body became accumulated in the soil. At the beginning of the experiment, the value of TN content in influent was $38.31 \pm 0.62 \mathrm{mg} / \mathrm{L}$, meaning that the TN load was very high, TN retention efficiency was inversely correlated with the load 
into the wetland system, with high loads reducing the efficiency of removal(Walton et al. 2020). According to previous research, at the beginning, nitrogen was mostly in the form of $\mathrm{NH}_{4}-\mathrm{N}$ and may have been partially sorbed onto the soil by cation exchange processes (Schipper et al. 2010). When conditions are anoxic in unharvested systems, $\mathrm{NO}_{3}-\mathrm{N}$ can be further transformed by denitrifying bacteria to $\mathrm{N}_{2}$ gases using carbon as both the electron donor and as the element for growth (Gumbricht 1993). Under flooded conditions, the soil will form a narrow oxidation zone of $0-1 \mathrm{~cm}$ on the wetland surface, and denitrification will occur when there is a lack of oxygen(Teiter and Mander 2005). This converts the nitrogen existing in the system into a gas and returns it to the atmosphere, thus optimizing the eutrophication environment. Under the condition of low waterlogged frequency, the TN content in the soil in the first week of waterlogged (the $21^{\text {st }}, 42^{\text {nd }}$, and $63^{\text {rd }}$ days) was lower than that in the previous week, indicating that the ability of the soil to degrade nitrogenous components occurred without additional nitrogen inputs; this trend was not obvious under the high waterlogged frequency condition.

In this experiment, the nitrogen content of the soil increased first and then decreased under different waterlogged depths. Under the high waterlogged depth condition, the nitrogen content decreased after 21 days; under the low waterlogged depth condition, a similar trend appeared after 35 days. When the water level is high, plants increase the rate of root oxygen secretion, providing more oxygen that can enter the roots; thus, the roots of plants can form an aerobic microenvironment and improve nitrification intensity. Moreover, the downward migration of $\mathrm{NO}^{3-}$ from water to soil affects the denitrification of nitrogen. Owing to the increase in the vertical diffusion flux of dissolved nitrogen, the denitrification rate will be significantly improved, and the removal efficiency of nitrogen will be higher. Therefore, it is predicted that with an increase in water level, the nitrogen storage of wetland soil will gradually decrease.

Irrespective of waterlogged conditions, the highest removal efficiency of TN appeared between the $14^{\text {th }}$ and $35^{\text {th }}$ days. This was the peak period of removal efficiency, possibly due to the plants at the beginning of the experiment requiring lots of nutrients to grow stably. At the end of the experiment, the TN concentration in the effluent increased slightly, reflecting the reduced demand for nutrients. And secondary pollution resulting from shoot death is a difficult problem that complicated the application of wetland plants for water purification (Huang et al. 2020). Although the removal rates were all at a high level, only a few effluent samples could meet the rate $V$ standard $(T N \leq 2 \mathrm{mg} / \mathrm{L})$ of the China environmental quality standard for TN in surface water.

Under the two waterlogged conditions, the removal rates of TN from the water were all greater than $60 \%$. After the 21st day, we saw peak TN removal. On the 35th day, the removal effect for the low waterlogged depth was significantly better than that of the high waterlogged depth; it is considered that the larger hydraulic load of the high waterlogged depth, which exceeded the optimal value, caused this difference. Within a certain range, the removal rate of nitrogen from water increases with the increase in nitrogen load. In this experiment, the TN concentration in the influent was $38.31 \pm 0.62 \mathrm{mg} / \mathrm{L}$, the purification effect of the plants was marked. Another possible reason is that the root system of Lythrum salicaria $L$. is highly developed and can absorb the nutrients from water very effectively to maintain growth demand, 
because we obversed that the underground biomass increased gradually during the experimental period. The root system of plants is directly proportional to the purification capacity of sewage, and the microorganism population on the root system is a key factor in the removal of pollutants. Plants synthesize oxygen through photosynthesis and release it to their roots through plant ventilation tissue. This process can form an aerobic-anoxic-anaerobic microenvironment around the roots, promoting process of nitrification or denitrification by the microorganisms and indirectly increasing the removal capacity of nitrogen pollutants (ARMSTRONG et al. 1992).

\section{Conclusion}

(1) Under the environment of eutrophication, the biomass of Lythrum salicaria $L$. increased rapidly during the experiment due to their extensive root system and vigorous spread, but it was not affected by waterlogged frequency (7days or14days) or waterlogged depth $(10 \mathrm{~cm}$ or $20 \mathrm{~cm})$.

(2) Under different waterlogged conditions, the removal rates of TN from the water were consistently greater than $60 \%$. When the growth trend slowed, the removal efficiency tended to be stable and then decreased. Therefore, when removing nitrogen from water by plants, we should consider regular harvesting to maintain the high oxygen content of the water and thus maximize the synergistic effect of plants and microorganisms.

(3) The removal efficiency of TN in soil and water was more obvious under low waterlogged frequency. High waterlogged depth may promote denitrification and nitrogen degradation in soil, and it is predicted that with an increase in water level, the nitrogen storage of wetland soil will gradually decrease. However, high nutrients loads may reduce the removal rate of TN in water.

(4) When implementing wetland water restoration projects, the conditions of waterlogged frequency and depth should be considered. Generally speaking, in our experiment, the waterlogged frequency was high and waterlogged depth was low compared with the actual conditions in most wetlands, but the nitrogen removal performance was pretty good. Therefore, biomanipulation, when appropriately timed in accordance with low waterlogged depths and high waterlogged frequencies combined with sediment dredging and other interventions, may be a low cost-high benefit tool for wetland eutrophication abatement.

Current studies elucidate, cultivation of plants in constructed wetland can successfully reduce the nitrogen concentration from wastewater and despite of it extensive research is still required, because different plant species have different nitrogen removal capacity, and in order to obtain better effect of wetland restoration, more different waterlogged conditions are needed.

\section{Declarations}

\section{Ethics approval and consent to participate}




\section{Consent for publication}

Not applicable

\section{Availability of data and materials}

Data are provided in the tables and figures in this paper.

\section{Competing interest}

The authors have no conflicts of interest

\section{Funding}

Ministry of Science and Technology of the People's Republic of China

\section{Authors' Contributions}

Lumeng Xie designed the experiment and write the manuscript, Ying Liu, Shiqiang Zhao and Liyi Dai participated this experiment and contributed to the paper outline, Mingxiang Zhang and Zhenming Zhang edited this paper and contributed to the writing. All authors read and approved the final manuscript

\section{Acknowledgements}

This research was supported by the National Key R\&D Program of China (2017YFC0505903). We extend thanks to many participants who helped us to do this experiment.

\section{References}

1. Abi Saab MT, Jammoul D, Makhlouf H et al (2018) Assessing the performance of constructed wetland for water quality management of a Southern Mediterranean river. Water and Environment Journal 32(4), 508-518. https://doi.org/10.1111/wej.12348

2. Aerts R, Chapin FS (1999) The Mineral Nutrition of Wild Plants Revisited: A Re-evaluation of Processes and Patterns. Advances in Ecological Research 30, 1-67. https://doi.org/10.1016/S00652504(08)60016-1 
3. Armstrong J, Armstrong W, Beckett PM (1992) Phragmites australis: Venturi- and humidity-induced pressure flows enhance rhizome aeration and rhizosphere oxidation. New Phytologist 120(2), 197207. https://doi.org/10.2307/2557658

4. Audet J, Zak D, Bidstrup J, Hoffmann CC (2020) Nitrogen and phosphorus retention in Danish restored wetlands. Ambio 49(1), 324-336. https://doi.org/10.1007/s13280-019-01181-2

5. Azhdarpoor A, Abbasi L, Samaei MR (2018) Investigation of a new double-stage aerobic-anoxic continuous-flow cyclic baffled bioreactor efficiency for wastewater nutrient removal. Journal of Environmental Management 211, 1-8. https://doi.org/10.1016/j.jenvman.2018.01.048

6. Bai J, Ouyang H, Deng W et al (2005) Spatial distribution characteristics of organic matter and total nitrogen of marsh soils in river marginal wetlands. Geoderma 124(1-2), 181-192. https://doi.org/10.1016/j.geoderma.2004.04.012

7. Bastlová Da, Květ JAN (2002) Differences in dry weight partitioning and flowering phenology between native and non-native plants of purple loosestrife (Lythrum salicaria L.). Flora 197(5), 0-340. https://doi.org/10.1078/0367-2530-00049

8. Bavandpour F, Zou Y, He Y et al (2018) Removal of dissolved metals in wetland columns filled with shell grits and plant biomass. Chemical Engineering Journal 331, 234-241. https://doi.org/10.1016/j.cej.2017.08.112

9. Bonanno G, Vymazal J, Cirelli GL (2018) Translocation, accumulation and bioindication of trace elements in wetland plants. Sci Total Environ 631-632, 252-261. https://doi.org/10.1016/j.scitotenv.2018.03.039

10. Busch J, Mendelssohn IA, Lorenzen B et al (2004) Growth responses of the Everglades wet prairie species Eleocharis cellulosa and Rhynchospora tracyi to water level and phosphate availability. Aquatic Botany 78(1), 37-54. https://doi.org/10.1016/j.aquabot.2003.09.002

11. Cheng FY, Meter KVV, Byrnes DK, Basu NB (2020) Maximizing US nitrate removal through wetland protection and restoration. Nature. https://doi.org/10.1038/s41586-020-03042-5

12. Deegan BM, White SD, Ganf GG (2007) The influence of water level fluctuations on the growth of four emergent macrophyte species. Aquatic Botany 86(4), 309-315.

https://doi.org/10.1016/j.aquabot.2006.11.006

13. Gan J, Chan SH, Eikaas HS, Sim CH (2011) Nutrient removal and plant biomass of 5 wetland plant species in Singapore. Water Practice and Technology 6(3).

14. Ge Z, An R, Fang S, Lin P et al (2017) Phragmites australis + Typha latifolia Community Enhanced the Enrichment of Nitrogen and Phosphorus in the Soil of Qin Lake Wetland. Scientifica (Cairo) 2017, 8539093. https://doi.org/10.1155/2017/8539093

15. Gumbricht T. (1993) Nutrient removal processes in freshwater submersed macrophyte systems. Ecological Engineering 2(1), 1-30. https://doi.org/10.1016/0925-8574(93)90024-A

16. Huang X, Lei S, Wang G, Zeng, B (2020) A wetland plant, Phalaris arundinacea, accumulates nitrogen and phosphorus during senescence. Environmental Science and Pollution Research 24(1). https://doi.org/10.1007/s11356-020-09285-z

Page 12/18 
17. J SK, Larry PR, J RR (2002) The Aerenchymatous Phellem of Lythrum salicaria (L.): a Pathway for Gas Transport and its Role in Flood Tolerance. Annals of Botany (5), 5. https://doi.org/10.1093/aob/mcf088

18. Jabońska $E$, Winkowska M, Winiewska M et al (2020) Impact of vegetation harvesting on nutrient removal and plant biomass quality in wetland buffer zones. Hydrobiologia, 1-17. https://doi.org/10.1007/s10750-020-04256-4

19. Li Y, Cheng C, Li X (2021) Research Progress on Water Purification Efficiency of Multiplant Combination in Constructed Wetland. IOP Conference Series: Earth and Environmental Science 632. https://doi.org/10.1088/1755-1315/632/5/052051

20. Ling Z, Li J (2018) Study on removal efficiency of nitrogen and phosphorus from agricultural wastewater by subsurface flow constructed wetland. ADVANCES IN ENERGY SCIENCE AND ENVIRONMENT ENGINEERING II: Proceedings of 2nd International Workshop on Advances in Energy Science and Environment Engineering (AESEE 2018). American Institute of Physics Conference Series.

21. Luo FL, Jiang XX, Li HL et al (2016) Does hydrological fluctuation alter impacts of species richness on biomass in wetland plant communities? Journal of Plant Ecology 9(4), 434-441. https://doi.org/10.1093/jpe/rtv065

22. Maltby E (1991) Wetland management goals: wise use and conservation. Landscape and Urban Planning 20, 9-18. https://doi.org/10.1016/0169-2046(91)90085-Z

23. McConnaughay KDM, Coleman JS (1999) Biomass allocation in plants ontogeny or optimality a test along three resource gradients. Ecology 80(8), 2581-2593. https://doi.org/10.1890/00129658(1999)080[2581:BAIPOO]2.0.C0;2

24. McHergui C, Besaury L, Langlois E et al (2014) A comparison of permanent and fluctuating flooding on microbial properties in an ex-situ estuarine riparian system. Applied Soil Ecology 78, 1-10. https://doi.org/10.1016/j.apsoil.2014.01.012

25. Meng B, Liu Jl, Bao K, Sun B (2019) Water fluxes of Nenjiang River Basin with ecological network analysis: Conflict and coordination between agricultural development and wetland restoration. Journal of Cleaner Production 213, 933-943. https://doi.org/10.1016/j.jclepro.2018.12.243

26. Mic A, Js A, Mh B et al (2019) Importance of plant species for nitrogen removal using constructed floating wetlands in a cold climate. Ecological Engineering 138(C), 126-132. https://doi.org/10.1016/j.ecoleng.2019.07.012

27. Moorberg CJ, Vepraskas MJ, Niewoehner CP (2015) Phosphorus Dissolution in the Rhizosphere of Bald Cypress Trees in Restored Wetland Soils. Soil Science Society of America Journal 79(1), 343355. https://doi.org/10.2136/sssaj2014.07.0304

28. Ou Y, Rousseau AN, Wang $L$ et al (2019) Identification of the alteration of riparian wetland on soil properties, enzyme activities and microbial communities following extreme flooding. Geoderma 337, 825-833. https://doi.org/10.1016/j.geoderma.2018.10.032 
29. Pan X, Ping Y, Cui L et al (2019) Nutrient Resorption from Leaves of Wetland Plants in a Constructed Wetland Depends on Green Leaf Nutrient Content and Life Form. Wetlands 1-9. https://doi.org/10.1007/s13157-019-01256-6

30. Rea N, Ganf G (1994) Water depth changes and biomass allocation in two contrasting macrophytes. Marine and Freshwater Research 45(8), 1459-1468. https://doi.org/10.1071/MF9941459

31. Rejmankova E (2005) Nutrient resorption in wetland macrophytes: comparison across several regions of different nutrient status. New Phytol 167(2), 471-482. https://doi.org/10.1111/j.14698137.2005.01449.x

32. Schipper LA, Robertson WD, Gold AJ et al (2010) Denitrifying bioreactors-An approach for reducing nitrate loads to receiving waters. Ecological Engineering 36(11), 1532-1543. https://doi.org/10.1016/j.ecoleng.2010.04.008

33. Sileshi A, Assayie A, Beyene A et al (2020) Water Purifying Capacity of Natural Riverine Wetlands in Relation to Their Ecological Quality. Frontiers in Environmental Science 8. https://doi.org/10.3389/fenvs.2020.00039

34. Suhani I, Monika, Vaish B et al (2020) Restoration, Construction, and Conservation of Degrading Wetlands: A Step Toward Sustainable Management Practices. Springer, Singapore. https://doi.org/10.1007/978-981-13-7665-8_1

35. Sun H, Xin Q, Luo H et al (2019) Effects of emerged plant on soil methane emission and nitrogen content in constructed wetland. IOP Conference Series: Earth and Environmental Science 218, 012135. https://doi.org/10.1088/1755-1315/218/1/012135

36. Teiter S, Mander Ü (2005) Emission of $\mathrm{N}_{2} \mathrm{O}, \mathrm{N}_{2}, \mathrm{CH}_{4}$, and $\mathrm{CO}_{2}$ from constructed wetlands for wastewater treatment and from riparian buffer zones. Ecological Engineering 25(5), 528-541.

37. Tootoonchi M, Bhadha JH, Lang TA et al (2018) Reducing drainage water phosphorus concentration with rice cultivation under different water management regimes. Agricultural Water Management 205, 30-37. https://doi.org/10.1016/j.agwat.2018.04.036

38. Unger IM, Kennedy AC, Muzika RM (2009) Flooding effects on soil microbial communities. Applied Soil Ecology 42(1), 1-8. https://doi.org/10.1016/j.apsoil.2009.01.007

39. Van Meter KJ, Basu NB, Van Cappellen P (2017) Two centuries of nitrogen dynamics: Legacy sources and sinks in the Mississippi and Susquehanna River Basins. Global Biogeochemical Cycles 31(1), 2-23. https://doi.org/10.1002/2016GB005498

40. Vojtíšková L, Munzarová E, Votrubová O et al (2004) Growth and biomass allocation of sweet flag (Acorus calamus L.) under different nutrient conditions. Hydrobiologia 518(1), 9-22. https://doi.org/10.1023/B:HYDR.0000025052.81373.f3

41. Walton CR, Zak D et al (2020) Wetland buffer zones for nitrogen and phosphorus retention: Impacts of soil type, hydrology and vegetation. Science of The Total Environment 727, 138709. https://doi.org/10.1016/j.scitotenv.2020.138709

42. Wang AO, Jiang XX, Zhang QQ et al (2015) Nitrogen addition increases intraspecific competition in the invasive wetland plantAlternanthera philoxeroides, but not in its native congenerAlternanthera 
sessilis. Plant Species Biology 30(3), 176-183. https://doi.org/10.1111/1442-1984.12048

43. WWAP (2017) Wastewater: The Untapped Resource, UNESCO, Paris, France.

44. Xie Y, An S, Wu B (2005) Resource allocation in the submerged plant Vallisneria natans related to sediment type, rather than water-column nutrients. Freshwater Biology 50(3), 391-402. https://doi.org/10.1111/j.1365-2427.2004.01327.x

45. Yu X, Konig T, Qi Z, Yongsheng G (2012) Nitrogen and phosphorus removal of locally adapted plant species used in constructed wetlands in China. Water Sci Technol 66(4), 695-703. https://doi.org/10.2166/wst.2012.200

46. Zak D, Gelbrecht J, Zerbe S et al (2014) How helophytes influence the phosphorus cycle in degraded inundated peat soils - Implications for fen restoration. Ecological Engineering 66, 82-90. https://doi.org/10.1016/j.ecoleng.2013.10.003

\section{Table}

Table 2 is not available in this version of the manuscript.

\section{Figures}



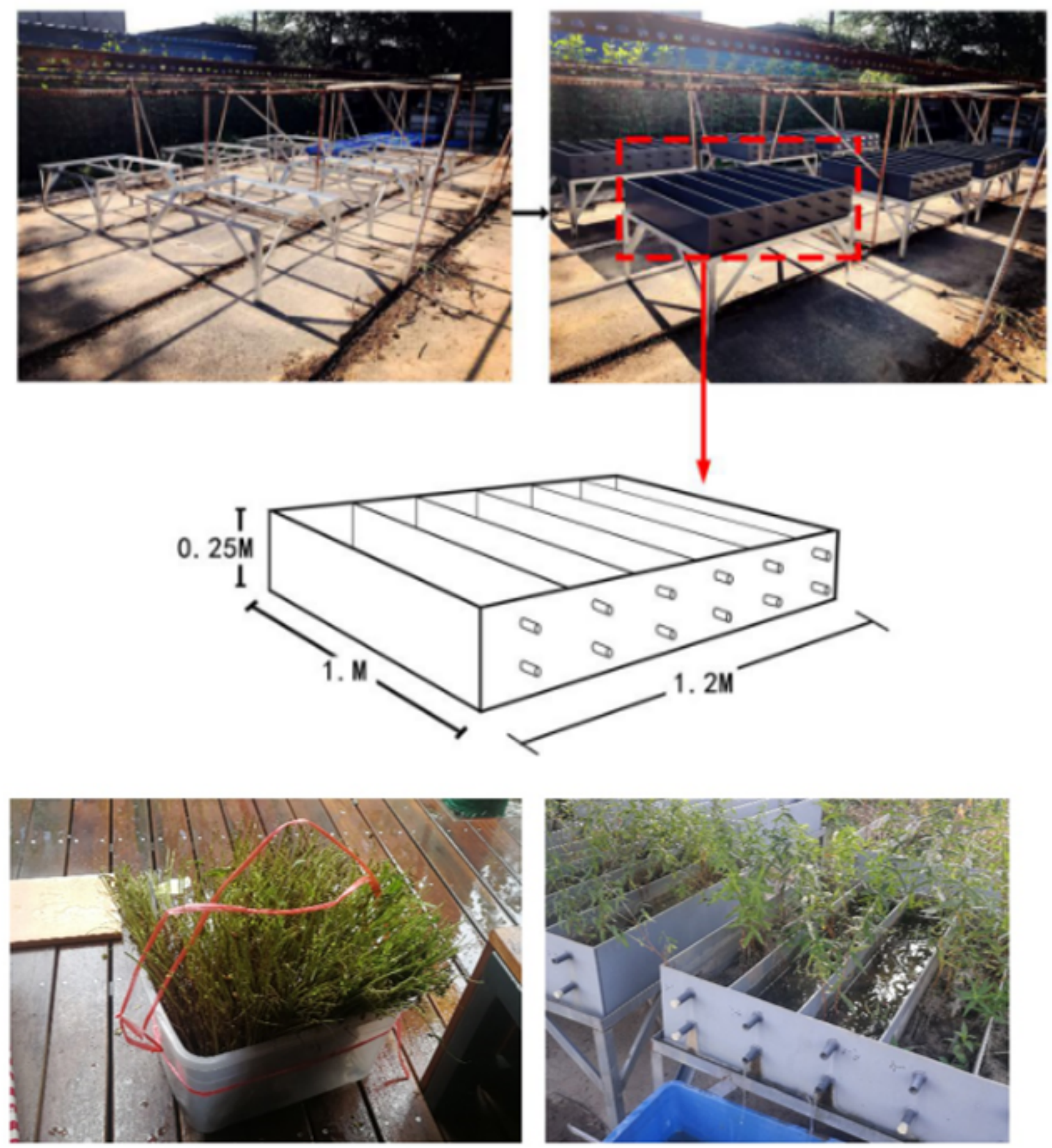

Figure 1

Diagram of flume 


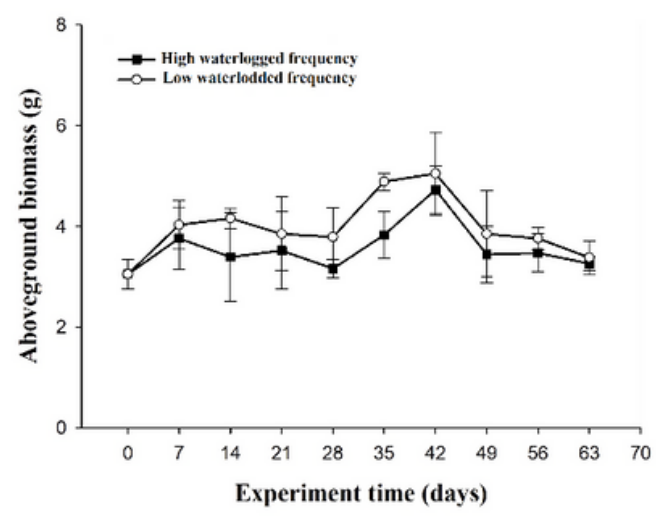

a

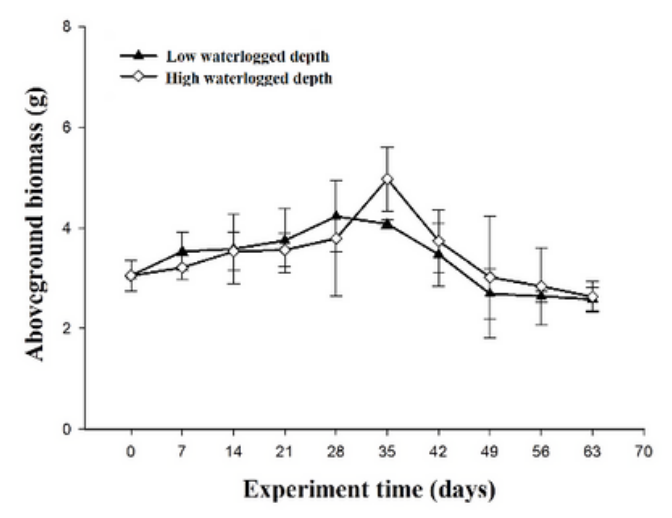

c

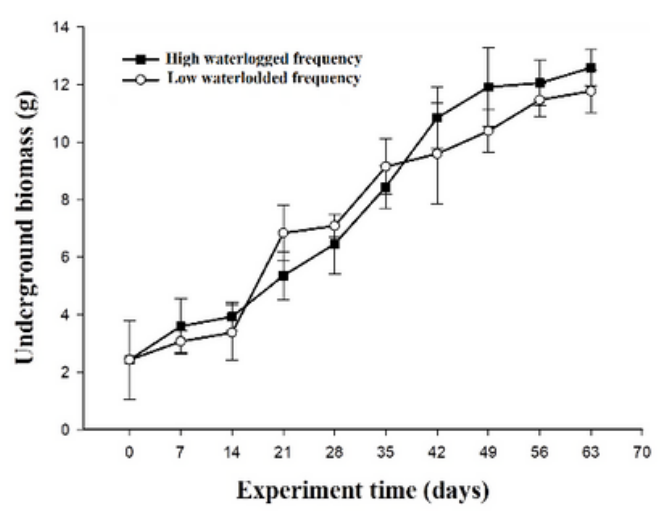

b

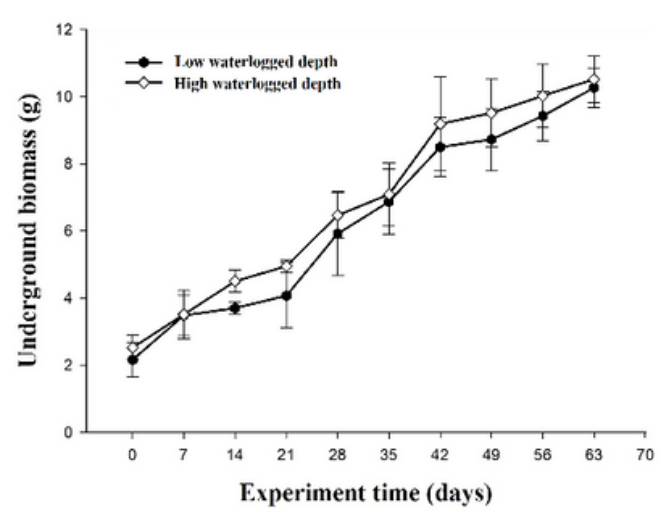

d

\section{Figure 2}

Dynamic changes in average biomass under different waterlogged conditions. a. aboveground biomass of different waterlogged frequencies; $b$. underground biomass of different waterlogged frequencies; $c$. aboveground biomass of different waterlogged depths; $d$. underground biomass of different waterlogged depths 

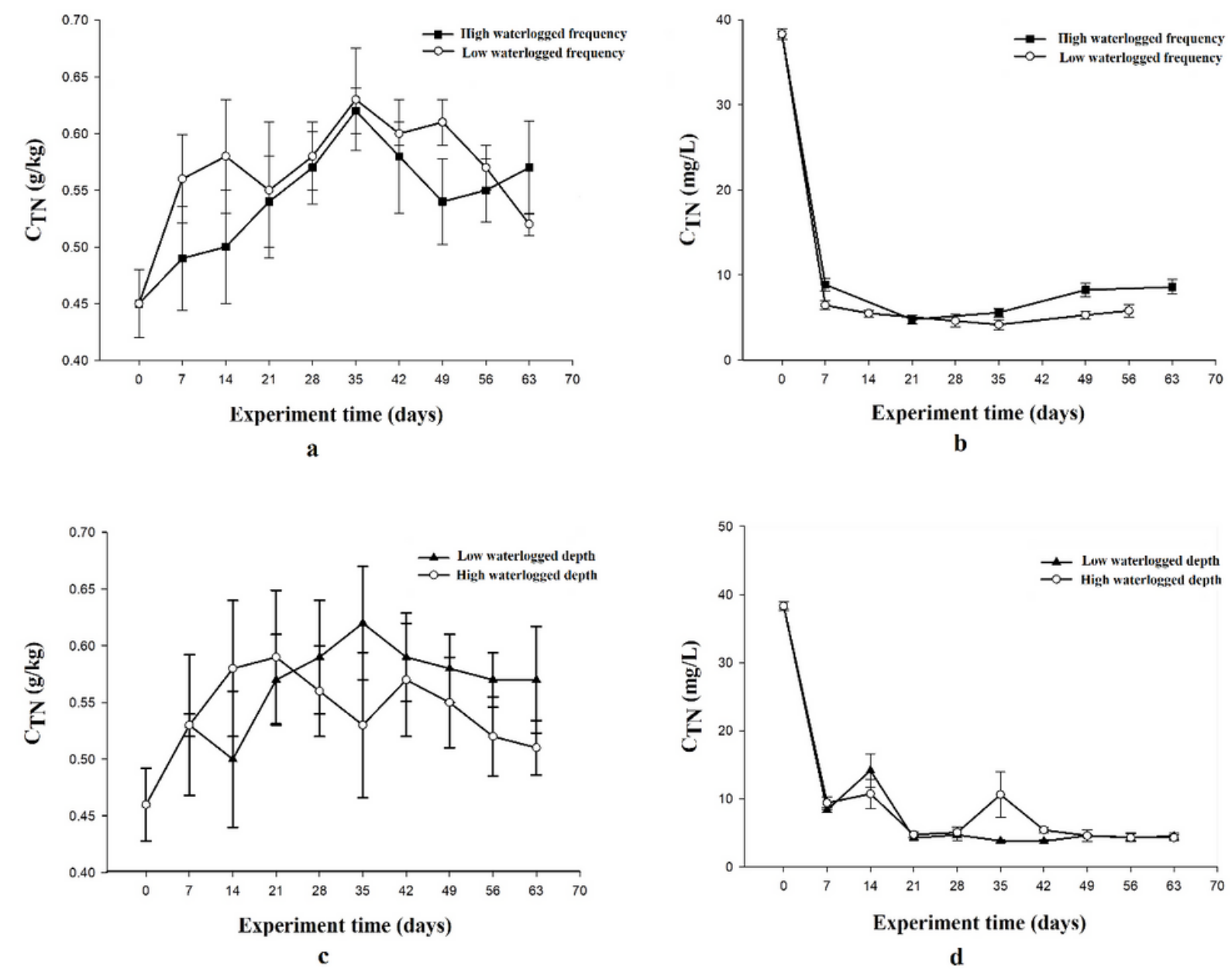

\section{Figure 3}

Dynamic changes in total nitrogen content of soil and effluent under different waterlogged conditions. a. The dynamic changes in soil TN content under different waterlogged frequencies; $b$. The dynamic changes in effluent TN content under different waterlogged frequencies; $c$. The dynamic changes in soil TN content under different waterlogged depths; $d$. The dynamic changes in effluent TN content under different waterlogged depth. 